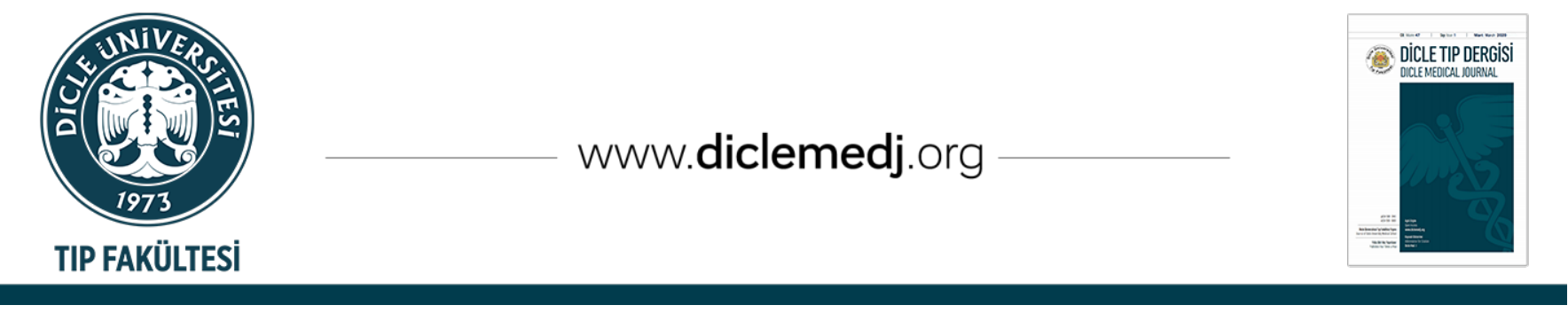

Original Article / Özgün Araştırma

\title{
Evaluation Of Patients With Previous C/S + Plasenta Previa Totalis İn 2017
}

\author{
Fatih Mehmet Findik ${ }^{\text {D }}$, Mehmet Sait Içen ${ }^{D}{ }_{1}$, Senem Yaman Tunç ${ }^{\text {i }}$ 1, Elif Ağaçayak ${ }^{\text {iD }}$, Mehmet \\ Siddik Evsen ${ }^{1}$, Ahmet Yalinkaya ${ }^{1}$ \\ 1 Department of Obstetrics and Gynecology, Dicle University, Faculty of Medicine, Diyarbakir, Turkey
}

Received: 29.06.2020; Revised: 31.08.2020; Accepted: 03.09.2020

\begin{abstract}
Objective: In this study, it was aimed to transfer different aspects from the literature in the management of patients who applied to our hospital with the diagnosis of placenta previa in 2017.

Metods: Patients who were admitted to our hospital in 2017 with a diagnosis of PP and who had undergone at least one previous cesarean section were included in the study.

Results: A total of 110 patients with the diagnosis of PP underwent surgery. The mean age of the patients was $33.02 \pm 5.1$ years. Spinal anesthesia was applied to $94(85.5 \%)$ patients. An abdominal Pfannenstiel incision was performed in 107 (97.3\%) patients. A total of four (3.6\%) patients underwent hysterectomy. A total of 95 (86.4\%) patients had accrete.

Conclusion: In conclusion, caesarean hysterectomy is recommended in patients with PP, especially those with accreta, however, the number of conservative treatment options has increased in recent years. Conservative surgery, which is frequently used in our clinic, is a comfortable option for the patient, and uterine-preserving surgery is very important for the preservation of fertility.
\end{abstract}

Keywords: placenta previa, uterine-preserving surgery, pfannenstiel incision

DOI: $10.5798 /$ dicletip.800011

Correspondence / Yazışma Adresi: Fatih Mehmet Findik, Department of Obstetrics and Gynecology, Dicle University, Faculty of Medicine, 21280, Diyarbakir, Turkey e-mail: fatihmf@gmail.com 


\section{Yılı Eski c/s + Plasenta Previa Totalis Hastalarının Değerlendirilmesi}

\section{Öz}

Amaç: Bu çalışmada 2017 yılı içinde hastanemize plasenta previa tanısı ile başvurmuş hastaların yönetiminde literatürden farklı yönleri aktarılması amaçlanmıştır.

Yöntemler: Hastanemizde 2017 yılı içinde başvurup plasenta previa (PP) tanısı alan ve geçmişinde en az bir defa sezaryen olan hastalar çalışmaya dahil edildi

Bulgular: Plasenta Previa tanısı ile toplamda 110 hasta ameliyat edilmiş olup hastaların yaş ortalaması 33,02 $\pm 5,1$ idi. Doksan dört $(\% 85,5)$ hastaya spinal anestezi uygulandı. $107(\% 97,3)$ hastada batına pfannenstiel insizyonla girildi. Toplamda $4(\% 3,6)$ hastaya histerektomi yapıldı. Toplamda $95(\% 86,4)$ hastada akreta tespit edildi.

Sonuç: Plasenta previa ile alakalı özellikle akreatası olan hastalarda önerilen sezaryen histerektomi olup son zamanlarda konservatif tedavi seçenekleri artmaktadır. Kliniğimizde sıklıkla kullanılan konservatif cerrahi hasta için konforlu bir durumdur. Hastalara uterus koruyucu cerrahi uygulanması infertilitesinin korunması açısından oldukça önemlidir.

Anahtar kelimeler: plasenta previa, uterus koruyucu cerrahi, pfannensteil insizyon.

\section{INTRODUCTION}

Although cesarean section rates vary between 0.4 and $40 \%$ among countries in the world, these operations have been increasing gradually in the last 30 years ${ }^{1}$. As with other surgeries, cesarean section has both short-term and long-term effects, as well as ongoing health effects in the postpartum period for mothers, children, and future pregnancies ${ }^{2}$.

One of the major complications of cesarean section is placenta previa (PP), which may occur in a subsequent pregnancy ${ }^{3}$. PP is a condition in which the placenta closes the internal os. It is diagnosed by ultrasonography (USG) and is seen in $0.4 \%$ of births, but the incidence varies regionally 4 .

No consensus has been reached regarding the timing of surgery or the surgical methods for patients with PP. The recommendation for patients with invasion anomaly is cesarean section hysterectomy at gestational week 3436, with general anesthesia primarily preferred $^{5}$. Additional invasive procedures, such as vascular balloon occlusion and hypogastric artery ligation, are also applied to the patients receiving conservative treatment.

Peri- and post-operative complication rates are high in patients with PP, with bladder injuries being the most common. Other complications include disseminated intravascular coagulopathy and vesicovaginal fistula ${ }^{6}$.

The aim of this study was to describe the differences between the management of patients admitted to our hospital in 2017 with a diagnosis of PP and the management practices described in the literature.

\section{METHODS}

This study covers the year 2017. The study was conducted in accordance with the principles of the 2013 Helsinki Declaration, and ethical approval was obtained from the ethics committee of our university before the study (ethical number: 2018-72).

Patients who were admitted to Dicle University Medical Faculty Hospital in 2017 with a diagnosis of PP and who had undergone at least one previous cesarean section were included in the study. Patients with PP with lower placental 
localization, with no history of cesarean section, or who underwent surgery before 24 weeks of gestation were excluded from the study. The diagnosis of PP was made by transabdominal ultrasound and confirmed by transvaginal ultrasound (General Electric Voluson 730 Pro). The presence of invasion was evaluated by Doppler USG.

In 2017, 1351 births occurred in our hospital. of these, 1067 were cesarean deliveries, for a rate of $78.9 \%$ in 2017 . The total number of PP patients included in the study was 110 (8.1\%). The information and data for these patients were obtained by screening their medical records. Evaluations included demographic information, such as age, gravida, parity, gestational week, and preoperative and postoperative hospitalization (days), as well as anterior-posterior placenta, blood volume, preoperative and postoperative hemoglobinhematocrit and intraoperative surgical procedures. Preoperative blood values were taken just before the operation. Postoperative blood values were taken 3 hours after the operation.

Surgical preparation: Patients with active bleeding or pain during their preoperative evaluation were hospitalized, whereas other patients were evaluated as outpatients with weekly controls. All patients were recommended to live 20 minutes away from the hospital, so accommodation was provided in the municipal guest house for patients who lived farther away. Patients who did not have pain and bleeding underwent elective caesarean section after 37 weeks of gestation, while caesarean section was performed in the same week of admission in patients with pain and bleeding. Four units of packed red blood cells were reserved preoperatively for each patient.

All operations were performed by gynecologists and obstetricians with at least 5 years of experience. The patients who desired preserving surgery were initially informed about the risks of surgery, and informed consent was obtained for uterine-preserving surgery. Spinal anesthesia was applied to the patients who were planned for conservative surgery during the operation, and general anesthesia was applied to the patients who were contraindicated for spinal anesthesia or who were undergoing cesarean hysterectomy. A Pfannenstiel incision was primarily preferred, and an umbilical median incision was performed on the patients undergoing hysterectomy. The placenta was totally removed in all patients who were planned for conservative treatment, and hemostatic suturing was used according to the presence of invasion. Placental invasion is defined as the removal of the placenta by hand from the tissue and bleeding from the placental bed In addition, the hypogastric artery was ligated or a balloon tamponade was applied in some patients.

The patients were called for follow-up at 1 and 6 months postoperatively.

Statistical analysis: SPSS version 21.0 was used for data analysis. The mean and standard deviation were used for descriptive statistics.

\section{RESULTS}

A total of 110 patients with the diagnosis of PP underwent surgery. The demographic data of the patients are shown in Table 1 . The mean age of the patients was $33.02 \pm 5.1$ years, mean gravida was $4.7 \pm 2.07$, and mean parity was $3.13 \pm 1.59$. The mean gestational week at surgery was $35.4 \pm 2.2$. Overall, $65.5 \%$ (72) of the patients were totalis from the anterior and $34.5 \%$ (38) were totalis from the posterior.

The patients were hospitalized for $2.89 \pm 5.7$ days preoperatively and for $2.5 \pm 1.59$ days postoperatively. Invasion was detected in 95 $(86.4 \%)$ patients. The mean number of previous cesarean sections was $2.29 \pm 0.99$. In total, $42.7 \%$ of the patients had undergone 3 or more previous cesarean sections. 
Table I: Demographic Data of Patients

\begin{tabular}{|l|l|}
\hline & Mean \pm SD (min-max) \\
\hline Age & $33,02 \pm 5,1(22-46)$ \\
\hline Gravidity & $4,7 \pm 2,07(2-12)$ \\
\hline Parity & $3,13 \pm 1,59(1-9)$ \\
\hline Gestational week & $35,49 \pm 2,2(26-39)$ \\
\hline Previous cesarean sections & $2,29 \pm 0,99(1-4)$ \\
\hline 2 & $29(26,4)$ \\
\hline Baby weight & $34(30,9)$ \\
\hline Preoperative hospitalization & $2,89 \pm 5,7(0-42)$ \\
\hline APGAR 5th & $33(30)$ \\
\hline Postoperative hospitalization & $2,5 \pm 1,59(1-14)$ \\
\hline A & $2682,36 \pm 558,5(750-3800)$ \\
\hline Pay & $5,64 \pm 1,3(2-9)$ \\
\hline
\end{tabular}

Spinal anesthesia was applied to 94 (85.5\%) patients. An abdominal Pfannenstiel incision was performed in 107 (97.3\%) patients. A total of four (3.6\%) patients underwent hysterectomy. A total of 95 (86.4\%) patients had accreta, and hemostatic suturing was used. A balloon tamponade was applied to three (2.7\%) patients. The hypogastric artery was ligated in two $(1.8 \%)$ patients. The amount of erythrocyte suspension transfusion was $0.78 \pm$ 1.9 units and 79 (71.8\%) patients required no blood transfusion. Surgical data are shown in Table 2.
Table II: Operative Outcomes

\begin{tabular}{|c|c|}
\hline Operative Outcomes & \\
\hline Spinal anesthesia n (\%) & $94(85,5)$ \\
\hline Pfannenstiel incision n (\%) & $107(97,3)$ \\
\hline $\begin{array}{l}\text { Intraoperative hemoglobin } \\
\text { value }(\mathrm{g} / \mathrm{dL})(\min -\max )\end{array}$ & $\begin{array}{l}11,3 \pm 1,45 \quad(8,32- \\
14,8)\end{array}$ \\
\hline $\begin{array}{l}\text { Intraoperative hemotocrit value } \\
\text { (\%) (min-max) }\end{array}$ & $\begin{array}{l}34,5 \pm 3,73 \\
(26,44-44,79)\end{array}$ \\
\hline $\begin{array}{l}\text { Postoperative hemoglobin value } \\
\text { (g/dL) (min-max) }\end{array}$ & $\begin{array}{l}10,33 \pm 1,30 \\
(7,42-14,12)\end{array}$ \\
\hline $\begin{array}{l}\text { Postoperative hemotocrit value } \\
\text { (\%) (min-max) }\end{array}$ & $\begin{array}{l}31 \pm 4,23 \quad(24,76- \\
36,05)\end{array}$ \\
\hline $\begin{array}{l}\text { Units of packed RBCs transfused } \\
\text { (min-max) }\end{array}$ & $0,78 \pm 1,9(0-16)$ \\
\hline Cesarean hysterectomy $\underline{\mathrm{n}}(\%)$ & $4(3,6)$ \\
\hline Vascular complication n (\%) & 0 \\
\hline Urinary complication n (\%) & $8(7,2)$ \\
\hline Postoperative infection $\underline{n}(\%)$ & $7(6,3)$ \\
\hline Uteovesikal fistula n (\%) & $2(1,8)$ \\
\hline
\end{tabular}

RBCs: Red Blood Cells

Bladder rupture developed in 8 (7.2\%) patients. Postoperative infection developed in seven patients and was treated with antibiotics in the hospital. In the long term, two patients developed uterovesical fistula. Vesicouterine fistula was diagnosed after resumption of the menstrual cycle. Patients presenting with hematuria during menstruation were diagnosed 3 months after the surgery at the 
earliest. None of the patients required relaparotomy. No mother died.

\section{DISCUSSION}

The fertility rate is gradually decreasing in Turkey and was reported as 2.1 in $2016^{7}$. In southeastern Anatolia, however, these rates are above $^{3}$. In other words, every woman gives birth to at least 3 children during their reproductive period. The rate of cesarean section in Turkey has increased over the years, from $21 \%$ to $53 \%$ between 2002 and 2016 . Caesarean section rates are especially high in university hospitals, with rates of $69 \%$ according to 2016 data. Primary cesarean rates in these hospitals range from $35.9 \% 8$.

Our hospital is the only tertiary care university hospital in the region of Turkey with the highest birth rate, and high-risk pregnancies are referred to our hospital. Remarkably, when compared to the literature, both caesarean section $(78.9 \%)$ and PP (8.1\%) rates are quite high in our hospital, which covers a population of approximately 12 million within the surrounding provinces.

The surgery choice for patients with PP is important. Given the recent increase in PP patients, treatment and follow-up of these patients in tertiary hospitals is not only important for the mother and baby, but they also reduce complications9. Delivery is recommended between $34+0$ and $35+6$ weeks of gestation, and general anesthesia is preferred $^{5,10}$. Caesarean hysterectomy is recommended in patients who are expected to have accreta, because a uterine-preserving approach is thought to increase bleeding and patient morbidity, especially in these patients ${ }^{11,12}$. The gestational week at birth in our hospital was consistent with the literature, but hysterectomy was performed in $3.6 \%$ of our patients and this result differed from the rate reported in the literature ${ }^{13}$. Another aspect of our study that differed from the literature was the predominant use of spinal anesthesia $(85.5 \%)$, rather than general anesthesia, because of conservative surgery. Although some studies have shown that spinal anesthesia is preferred in patients undergoing conservative surgery, the low number of cases is noteworthy ${ }^{14}$.

In the literature, a median incision below the umbilicus is commonly preferred as the skin incision, whereas the Pfannenstiel incision can be preferred in patients who are not considered for hysterectomy. The use of a Pfannenstiel incision instead of an umbilical median incision is considered to accelerate healing, cause less incisional hernia, and be more cosmetic for the patien ${ }^{15,16}$. The main reason for choosing an umbilical median incision is for removal of the baby from the uterus without touching the placenta, which is more likely to occur when an incision into the fundus is required. One other study in the literature primarily applied a Pfannenstiel incision ${ }^{17}$.

The first method applied as conservative surgery involves leaving the whole or part of the placenta untouched, with subsequent follow-up after the procedure ${ }^{18}$. This method is not widely used today due to the high rate of complications (sepsis, late-term bleeding, and delayed hysterectomy). Currently, other methods, such as intracavitary suture, segmental resection, and double incision techniques, are used to protect the uterus. The success rate of the intracavitary suture technique has been reported to be quite high (successful in 58 of 62 patients) ${ }^{19}$. Unlike our study, patients without a history of cesarean section were also included in the previous study ${ }^{19}$. By contrast, a segmental resection technique has been performed in only a small group of patients and the suitability of this technique to all PP cases has not been discussed ${ }^{20}$. In a study that used a double incision technique, in which the fetus was removed by a separate incision from the area close to the fundus and a second incision was 
applied to the uterus for the placenta, an umbilical median skin incision was performed at a high rate of $83 \%^{21}$.

Other procedures, such as vascular balloon occlusion, hypogastric artery ligation, and uterine tamponade, have been used in some patients $^{22,23}$. One study with extensive patient participation in which balloon occlusion was performed indicated that the need for hysterectomy decreased with increasing obstetric experience in this subject ${ }^{24}$. By contrast, the amount of red blood cells given to patients was quite high, as the mean erythrocyte transfusion was 6.54 and 7.42 units, in contrast to the 0.78 units used in the present study. In addition, the postoperative hospital stay of patients was reported as 9-10 days, which is considerably longer than our results ${ }^{24}$.

The large amount of erythrocyte transfusion and the longer hospitalization in the previous study, despite the reduced hysterectomy rate, is also noteworthy ${ }^{24}$. Kuhn et al. have shown that prophylactic use of hypogastric artery ligation does not reduce the amount of bleeding and that this method is ineffective due to rich collaterals in the region ${ }^{25}$. Similar results have been obtained in other studies ${ }^{26}$.

In the present study, the hysterectomy rate was 3.6\%. A study by Kong and To that included 215 PP cases reported a rate of $1.8 \%$. Unlike the present study, only 57 (26.5\%) of the patients in the previous study had a history of cesarean section, which reduces the rate of cesarean section $^{27}$. A study by Sak et al., in which hysterectomy was performed on all patients, did not indicate how many patients were diagnosed with PP, and both bladder injury and postoperative hospital stay were higher than in our study ${ }^{28}$.

Only limited data are available in the literature regarding the time spent in the hospital during the period prior to the operation, but the available studies have shown no difference in terms of maternal and fetal outcomes for outpatients or inpatients ${ }^{29,30}$. In these studies, the prenatal hospitalization period was 19-22 days, which is quite long compared to our study.

\section{CONCLUSION}

In conclusion, caesarean hysterectomy is recommended in patients with $\mathrm{PP}$, especially those with accreta, however, the number of conservative treatment options has increased in recent years. Conservative surgery, which is frequently used in our clinic, is a comfortable option for the patient, and uterine-preserving surgery is very important for the preservation of fertility. The choice of Pfannenstiel skin incision is a priority of the patients in terms of cosmetic appearance. However, further studies are needed to investigate the psychological effects of the Pfannenstiel skin incision and of surgery without hysterectomy performed on most patients.

Ethics Committee Approval: This study covers the year 2017. The study was conducted in accordance with the principles of the 2013 Helsinki Declaration, and ethical approval was obtained from the ethics committee of our university before the study (ethical number: 2018-72).

Declaration of Conflicting Interests: The authors declare that they have no conflict of interest.

Financial Disclosure: No financial support was received.

\section{REFERENCES}

1. Althabe F, Sosa C, Belizan JM, et al. Cesarean section rates and maternal and neonatal mortality in low-, medium-, and high-income countries: an ecological study. Birth. 2006; 33: 270-7.

2. Betran AP, Torloni MR, Zhang JJ, et al. WHO Statement on Caesarean Section Rates. BJOG. 2016; 123: 667-70.

3. Evsen MS, Sak ME, Özkul Ö, et al. Acil peripartum histerektomi. Dicle Tıp Dergisi. 2009; 36: 23-7. 
4. American College of O, Gynecologists, Society for Maternal-Fetal M. Obstetric Care Consensus No. 7: Placenta Accreta Spectrum. Obstet Gynecol. 2018; 132: e259-e75.

5. Fox KA, Shamshirsaz AA, Carusi D, et al. Conservative management of morbidly adherent placenta: expert review. Am J Obstet Gynecol. 2015; 213: 755-60.

6. Publications Committee SfM-FM, Belfort MA. Placenta accreta. Am J Obstet Gynecol. 2010; 203: 430-9.

7. Gemicioğlu S, Şahin H, Emrah ER. Türkiye'de Doğurganlık Analizi: Gelecekteki Doğurganlık Tercihlerinin Önemi. Sosyoekonomi. 2019; 27: 22334.

8. Kıyak H, Bolluk G, Canaz E, et al. Sezaryen oranlarını Robson On Gruplu Sinıflandırma Sistemi ve perinatoloji (tersiyer merkez) verileri doğrultusunda konuşmak. Perinatal Journal. 2019; 27: 89-100.

9. Bartels HC, Rogers AC, O'Brien D, et al. Association of Implementing a Multidisciplinary Team Approach in the Management of Morbidly Adherent Placenta With Maternal Morbidity and Mortality. Obstet Gynecol. 2018; 132: 1167-76.

10. Lilker SJ, Meyer RA, Downey KN, et al. Anesthetic considerations for placenta accreta. Int J Obstet Anesth. 2011; 20: 288-92.

11. Karaman E, Kolusari A, Cetin O, et al. Local resection may be a strong alternative to cesarean hysterectomy in conservative surgical management of placenta percreta: experiences from a tertiary hospital. J Matern Fetal Neonatal Med. 2017; 30: 947-52.

12. Wong HS, Hutton J, Zuccollo J, et al. The maternal outcome in placenta accreta: the significance of antenatal diagnosis and non-separation of placenta at delivery. N Z Med J. 2008; 121: 30-8.

13. Clark HR, Ng TW, Khan A, et al. Placenta Accreta Spectrum: Correlation of MRI Parameters With Pathologic and Surgical Outcomes of High-Risk Pregnancies. AJR Am J Roentgenol. 2020; 214: 141723.

14. Collins SL, Alemdar B, van Beekhuizen HJ, et al. Evidence-based guidelines for the management of abnormally invasive placenta: recommendations from the International Society for Abnormally Invasive Placenta. Am J Obstet Gynecol. 2019; 220: 511-26.

15. Köstü B, Önder E, Özer A, et al. Total plasenta previa olgularında erkek fetüs hakimiyeti. Perinatoloji Dergisi. 2015; 23: 84-8.

16. Rauf M, Ebru C, Sevil E, et al. Conservative management of post-partum hemorrhage secondary to placenta previa-accreta with hypogastric artery ligation and endo-uterine hemostatic suture. J Obstet Gynaecol Res. 2017; 43: 265-71.

17. Mc KR, D'Errico E. Placenta accreta: clinical manifestations and conservative management. $\mathrm{N}$ Engl J Med. 1951; 245: 159-65.

18. Sentilhes L, Ambroselli C, Kayem G, et al. Maternal outcome after conservative treatment of placenta accreta. Obstet Gynecol. 2010; 115: 526-34.

19. Acar A, Ercan F, Pekin A, et al. Conservative management of placental invasion anomalies with an intracavitary suture technique. Int J Gynaecol Obstet. 2018; 143: 184-90.

20. Kilicci C, Sanverdi I, Ozkaya E, et al. Segmental resection of anterior uterine wall in cases with placenta percreta: a modified technique for fertility preserving approach. J Matern Fetal Neonatal Med. 2018; 31: 1198-203.

21. Polat I, Yucel B, Gedikbasi A, et al. The effectiveness of double incision technique in uterus preserving surgery for placenta percreta. BMC Pregnancy Childbirth. 2017; 17: 129.

22. Ferrazzani S, Guariglia L, Triunfo $S$, et al. Conservative management of placenta previaaccreta by prophylactic uterine arteries ligation and uterine tamponade. Fetal Diagn Ther. 2009; 25: 4003.

23. Makary M, Chowdary P, Westgate JA. Vascular balloon occlusion and planned caesarean hysterectomy for morbidly adherent placenta: A systematic review. Aust N Z J Obstet Gynaecol. 2019; 59: 608-15.

24. Peng W, Shen L, Wang S, et al. Retrospective analysis of 586 cases of placenta previa and accreta. J Obstet Gynaecol. 2020; 40: 609-13. 
25. Kuhn T, Martimucci K, Al-Khan A, et al. Prophylactic Hypogastric Artery Ligation during Placenta Percreta Surgery: A Retrospective Cohort Study. AJP Rep. 2018; 8: e142-e5.

26. Kong CW, To WWK. Risk factors for severe postpartum haemorrhage during caesarean section for placenta praevia. J Obstet Gynaecol. 2020; 40: 479-84.

27. Sak S, Barut M, Incebiyik A, et al. Management of peripartum hysterectomies performed on patients with placenta percreta in a tertiary central hospital. J Matern Fetal Neonatal Med. 2019; 32: 883-8.
28. Droste S, Keil K. Expectant management of placenta previa: cost-benefit analysis of outpatient treatment. Am J Obstet Gynecol. 1994; 170: 1254-7.

29. Paraskevaides E, Noelke L, Afrasiabi M. Internal iliac artery ligation (IIAL) in obstetrics and gynaecology. Eur J Obstet Gynecol Reprod Biol. 1993; 52: 73-5.

30. Love CD, Fernando KJ, Sargent L, et al. Major placenta praevia should not preclude out-patient management. Eur J Obstet Gynecol Reprod Biol. 2004; 117: 24-9. 